\title{
Editorial
}

\section{New steps for our Journal}

International Journal of Disclosure and Governance (2007) 4, 145-147. doi:10.1057/palgrave.jdg.2050059

My last Editorial concerned the steps taken by the audit industry to change its business model to better match the demands of the marketplace. In a similar vein, this Editorial discusses several important changes in our Journal that are designed to change the way in which it interacts with its community of readers.

\section{INAUGURAL INTERNATIONAL JOURNAL OF DISCLOSURE AND GOVERNANCE CONFERENCE}

First, and perhaps most significant of all, is that coinciding with the publication of this issue there will take place one of the most important milestones in the Journal's history, the holding of its inaugural conference, on 21st September, 2007, at Rutgers Business School in Newark, New Jersey (http://raw.rutgers.edu/IJDG/).

The purpose of the conference is to commemorate the fifth anniversary of the signing into law on 30th July, 2002 of the Sarbanes-Oxley Act (SOX), and particularly its Section 404 provision on internal control over financial reporting. Section 404, a frequent topic of papers in this Journal, is easily the most contentious - some would say infamous business regulation in a generation. The conference aims to provide a public forum to candidly debate the impact and future of the legislation, bringing together users and preparers of financial information, executives, regulators, legislators and auditors.

The conference will be themed around four key unresolved issues:

1. Has SOX helped or hurt US business? Have US capital markets and firms been put a competitive disadvantage by SOX, especially against the booming London stock exchange? What is the reality beyond the rhetoric? Will the announced SEC and PCAOB regulatory changes improve the situation, or are they a classic case of too little, too late? Is Congressional intervention necessary and likely?

2. Has SOX improved audit opinion reliability? Are SOX 404 audit opinions more reliable and trustworthy than those being issued in the US today by non-accelerated filers and private companies? Will the litigation exposure of external auditors expand exponentially if ICFR predictions and audit opinions prove wrong down the road?

3. Has SOX improved financial statement reliability? The rationale for SOX 404 is that better controls over the financial reporting process results in better and more accurate financial statements. Has that proven to be the case? And is the cost worth the benefit? How successful are current methods and tools used to implement SOX? How successful is 404 at anticipating senior executive directed frauds? Is a separate fraud audit required or are current rules adequate?

4. Has the US gone out on a limb with SOX, or got a head start? Canada, the UK, Europe and Japan have concluded after careful study that the cost of the current US SOX 404(b) regulatory regime exceeds the benefits. Will these countries change their mind after the new 'top-down/risk-based' guidance from the SEC is issued in final or will US listed companies have to absorb higher compliance costs? Are US SOX 404 audit opinions 
more reliable than audit opinions being issued by auditors on financial statements elsewhere in the world? If there are significant global differences in audit opinion quality, should investors, bankers, regulators and other users of financial be told that there are now different grades of audit opinions, and are US firms benefiting through a lower cost of capital?

Obviously no one conference will be able to cover all these topics, but it is our hope that many important and interesting discussions and debates will take place during this one-day conference.

I must apologise for not providing timely information on the conference, but it was only earlier this year that I made the decision to just go ahead with it rather than delay it any further. As I write this Editorial, it is still open to question whether or not this is an overly ambitious timetable, but a major success factor is the securing of the sponsorship, participation and marketing channels of the Institute of Management Accountants (IMA), as well as the support of the Open Compliance and Ethics Group (OCEG). Thanks to their sponsorship and participation, we are on track for a first rate conference with speakers from Paisley Consulting, the IMA, the AICPA's Center for Audit Quality, the PCAOB, the SEC, and perhaps most intriguing of all, a panel of senior congressional staffers on the view from the US Congress of the problems in implementing the SarbanesOxley Act and legislative alternatives to it. The proceedings of the conference will be published in a special issue of the Journal so that all our readers will be able to access the views of these key players in the future of this most controversial piece of business regulation.

Our goal is to make this conference an annual event. Given the wide domain of the Journal, we have the freedom to examine many different issues - for example, one topic that we are currently mulling over for a future conference has the rather provocative theme: Can lawsuits lead to better governance? With more advance warning, we welcome the participation of the entire journal community for the 2008 International Journal of Disclosure and Governance Conference. Please contact me with feedback and suggestions for conference themes, locations, timing, sponsorship, and most important of all, if you wish to present your ideas at the next conference.

\section{LETTERS TO THE EDITOR}

In my previous Editorial I promised that this Journal would take the lead in the discussion over the creation of a 21 st century business reporting system. The first step in keeping that promise is the Alles and Vasarhelyi article in this issue on reengineering the process by which financial statements and prepared and used by investors. This is far from a definitive statement, rather, it is designed to further the conversation and open up avenues for dialogue.

Speaking of which, we once received from a colleague this response to our proposal that financial statements should aggregate less and communicate more of the unfiltered data of the firm: 'Financial statement users are not always as sophisticated as one might think, even experienced analysts. They simply do not understand, or are unaware of some of the more complex issues accountants currently address (say, eg, pensions and financial instruments). Analysts generally recognise this and willingly leave such matters to accountants to deal with on their behalf. The shortcomings of the current system that the analysts tend to complain about are often quite mundane and sometimes involve issues that are intractable (but the analysts don't realise it). Some of the analysts I have heard from clearly want standards to help them make sense of the information companies provide. The supposition that analysts would be able to go data mining in publicly available corporate databanks to develop the information they need is laughable. The analysts I know would have neither the time nor the ability to do that. In my experience, analysts are barely able to cope with the volume and nature of information currently available to them, given the outputs they are expected to provide. For example, some analysts have to sift periodically through the 
entire universe of public companies, or substantial subsets of that universe, to identify potential candidates for closer scrutiny. They do so on the basis of a very few, quite crude analytical screens based on current reporting. They could do no more with the models available to them. Building better models to use raw corporate data is likely impracticable. If it were attempted, it would likely largely replicate the companies' accounting systems. Companies might find it attractive to shift the cost and effort of external financial reporting onto the shoulders of the users, but would not be able to avoid the cost and effort of maintaining their own systems for internal reporting.'

The point of repeating this comment at length here is not to debate its rights and wrongs - and I would like to think that many of our readers, especially the analysts, would not agree with it - but rather, for it to serve as an introduction to a new feature of the Journal: a letters to the editor section. This Journal ultimately belongs to its readers, who alone determine whether it stands or falls. Thus, it is time to foster a two-way conversation between readers, writers and editors that provides feedback, commentary and direction to the Journal. For example, while I question the premise of the above letter, I applaud the writer for having the courage to express such provocative views and acknowledge with appreciation the impetus it gave my coauthor and myself to refine and better support our original position.

It is my intention from the next issue to publish selected letters to the editor, so that our authors and readers can similarly benefit from the experience and knowledge of our community. The shorter, the wittier and the more substantive the letter, the more useful it will be to our community and the more likely it is to be published. The obvious subject matters for a letter are your thoughts on the papers (and editorials!) published in the Journal, but I also welcome letters that draw attention to important issues in the governance and disclosure area that need to be better covered in the Journal, or notes which address significant events in the subject area of the Journal.

This is an experiment whose success depends, as always, on the support and good sense of our readers. Please address letters to the editor to alles@business.rutgers.edu.

The best form of communication is not a letter, however, but a complete paper that expresses ideas fully and in depth. I encourage more of our readers to write for the Journal and will be happy to discuss how to translate ideas into papers with you. This Journal offers the freedom to discuss a variety of areas that cover the entire spectrum of governance and disclosure - a breadth rare in a world of increasingly specialised and narrowly targeted journals - and I encourage our readers to take advantage of that opportunity.

An example of an exciting project already underway is an entire issue devoted to India. Issue Editor, Professor Suresh Govindaraj of Rutgers University, has assembled a stellar group of the movers and shakers of Indian business and government to write on governance, financial reporting, the legal environment and business practice in this emerging Asian superpower.

Similar special issues are planned for China and Latin America. Again, I invite the participation of our readers in writing for these issues, or for proposing other special issue topics including offers to serve as the issue editor. Allowing me to delegate my role as editor would be the ultimate symbol that this is a Journal that is truly for and of its community of readers and writers.

Michael Alles Issue Editor 